\title{
ARTICLES
}

\section{TERRORISM, BANDITRY AND HIRABAH: ADVANCING NEW SHARIAH PERSPECTIVES}

\author{
Mohammad Hashim Kamali*
}

\begin{abstract}
Hirabah is the nearest Shariah legal concept to terrorism. Modern technological change, however, has altered the nature of this crime so much that corresponding adjustments in the law of hirabah are inevitable. Remote control devices, precision device-timing, vastly destructive weapons, and even suicide bombings were not considered by early Muslim jurists in their scholastic articulations of hirabah. The Qur'anic conception of this crime, on the other hand, is broad enough to accommodate the needed adjustments, and which is what this article attempts to do - in other words, to reconnect the fiqh of hirabah to its Qur'anic origins. This is necessary as, in its global reach, the scourge of contemporary terrorism has greatly pained and anguished, not only Muslims, but humanity at large. The nature of the phenomenon before us demands suitable Shariah responses. To facilitate this, we have attempted to comprehend contemporary terrorism in its own terms. The discussion therefore begins by defining terrorism and hirabah. A review of the principal Qur'anic verse on hirabah is presented at the outset and then followed by a review and analysis of the figh of hirabah in the expositions of the leading schools of Islamic law. Being one of the prescribed hudud crimes, the Qur'an provides a four-fold punishment for hirabah, but while also opening the prospect of repentance and pardon for its perpetrators under certain conditions, and which Muslim scholars have elaborated upon in their deliberations. Yet what they have said in this regard has naturally been bound by the conditions of their own environment and time. This has involved elements of interpretation and speculative ijtihad. In our own attempt to bridge the gap between the fiqhi conception of hirabah and contemporary terrorism, we look into contemporary opinion and research on this phenomenon so as to encapsulate its salient new features. Terrorism has been overshadowed, to some extent, by the clamour generated by the socalled 'clash of civilisations,' by Islamophobia and by confrontational politics, at the expense of reflective Shariah responses to issues. Muslim scholars have provided some through the issuance of fatwa and scholarly opinion, which we also review in a separate section below. The article ends with a conclusion and set of actionable policy recommendations.
\end{abstract}

Keywords: extremism and terrorism, Qur'an, fiqh, interpretation, suicide bombing, punishment, repentance. 


\section{Hirabah and Terrorism: Definition and Meaning}

Literally meaning to fight or wage war, hirabah is held by the general consensus of all the leading schools of jurisprudence, both Sunni and Shia, to be a major sin and a capital hadd crime. Concerning terrorism, it has proven difficult to find a comprehensive definition; as many years of fruitless debate in the United Nations shows, it cannot be defined to the satisfaction of everyone. The one factor that underlines all terrorism, however, also underlies hirabah: the desire to cause fear, terror, and insecurity in society through the indiscriminate use of violence, often for political ends. This characterisation of both terrorism and harabah covers acts of terror perpetrated by individuals, groups and even states (as exercised by Israel against the Palestinian people).

Sherman Jackson compares hirabah with 'domestic terrorism' in the United States, finding similarities between them. According to a definition attributed to the FBI, domestic terrorism is "the unlawful use of force or violence against persons or property to intimidate or coerce a government, the civilian population, or any segment thereof, in furtherance of political goals." Jackson notes that a principal ingredient of this definition is its focus on an inducement or spread of fear, which is also how Muslim jurists have described hirabah. Another aspect in common between hirabah and 'domestic terrorism' is the lack of a personal relationship between the parties, in the sense that the victim and killer may not even know one another. We shall have more to say on hirabah in our review of the Qur'an and hadith on hirabah, and then the figh of hirabah in separate sections below.

\section{Hirabah in the Qur'an and Hadith}

It is due to the extreme gravity of hirabah that the Qur'an calls its perpetrators, as those who spread terror and insecurity amongst the people, the ones who wage war on God and His Messenger. Hirabah in the Qur'an is envisaged as a composite crime, subsuming banditry, highway robbery, terrorism, theft, and murder. It is a hadd crime consisting usually, but not necessarily, of collective or group activity committed by more than one person on behalf of that group; if a crime is committed by just one of the bandits, all of them are liable for the consequences. The principal Qur'anic verse on hirabah is as follows:

The only punishment of those who wage war on God and His Messenger and strive with might and main for mischief-making through the land (fasad fi'l-ard) is execution or crucifixion, or mutilation of their hands and feet on alternate sides, or banishment from the land. Such will be their disgrace in this world, and in the Hereafter theirs will be a heavy 
punishment. Save those who repent before you overpower them. And know that God is Forgiving, Most Merciful. (al-Ma'idah, 5:33-34)

In a renowned hadith that is present in all the major hadith collections, the Prophet said: "One who carries arms against us is not one of us [man hamala 'alayna al-silaha fa-laysa minna]." The Prophet endorsed this in another hadith, saying that "One who unleashes his sword on us is not one of us [man salla "alayna al-sayfa fa-laysa minna]."

The Qur'anic phrase "waging war on God and His Messenger" placed jurists in a quandary as to its precise import and implications. A generic expression, it was evidently not meant literally. Since it is immediately followed by "making mischief in the land-fasad fi'l-ard," the two phrases have been read together in order to provide a clearer understanding of the verse. Yet this latter phrase, too, is less than specific, for 'fasad fil-ard' can also include a variety of criminal activities and transgressions. Indeed, it has even been suggested that the latter phrase is wider than the former, in that spreading 'corruption in the earth' can include criminal activities that may not qualify as hirabah as such. Hence, the relationship between the two phrases is seen as one of the particular (khass) to the general ('aam), in which case hirabah is seen as only one of the many manifestations of 'fasad fi'l-ard.' Al-Shawkani (d.1835/1250) wrote that the manifest meaning of 'fasad fi'l-ard' is broad enough to subsume not only highway robbery, but also propagation of false deities (shirk), destruction of people's lives, looting their properties and attacking their dignity, as well as the destruction of trees, waterways and livestock, aggressive dictatorship and so forth. ${ }^{2}$ Some commentators have also included recidivist thieves and burglars, notorious rapists and homosexuals under hirabah, as those who's evil and mischief-making cannot be stopped other than by execution.

Most, however, have understood the verse under review as referring to bandits and those who stage armed rebellion, thereby threatening normal peace and order. Ibn Hazm al-Zahiri (d.1064/456) observed that, since many other crimes, such as adultery and theft, were specifically mentioned in the Qur'an with assigned, quantified penalties, the verse of hirabah must refer to the unspecified crime of banditry (qat' al-tariq). Yet to read that particular crime into the meaning of hirabah and 'spreading of corruption in the earth' is evidently an interpretation, albeit one that seems to have found common acceptance. In sum, unlike the other hudud crimes, which are mentioned specifically by name, hirabah/banditry is arrived at through juristic construction and general consensus (ijma $\left.{ }^{\prime}\right){ }^{3}$

It is not only natural but necessary for Muslim scholars and jurists to continue this interpretative endeavour by subsuming the global scourge of contemporary terrorism under the umbrella of the Qur'anic concept of "waging war against God 
and His Messenger," which is arguably one of the greatest instances of spreading corruption in the earth. This understanding of hirabah is clear from a simple reading of the Qur'anic text, without any need to bring in any methodology or formula, such as analogy (qiyas) or even ijtihad. Muslim jurists have commonly understood "waging war on God and His Messenger" to mean waging war on the people, including (of course) the Muslim community. This is clear enough.

In the fiqh sources, juristic thought has focused on a variety of related themes, raising questions as to whether hirabah can be committed by an individual or whether it is a collective crime that only a group can perpetrate. Likewise, can it be committed within a city area or only outside of it; must it involve the use of weapons; and must it always be politically motivated? Although most of these questions are also relevant to discussions about contemporary terrorism, the availability of remote devices and a host of other more recent developments would appear to have made at least some of them almost totally redundant. Moreover, certain manifestations of contemporary terrorism, such as suicide bombing, were not familiar to earlier schools of thought and therefore tend to fall outside the scope of their writings. One also finds that fiqh writings on hirabah are internally diverse with much that is not supported by general consensus. It thus remains open to further development and ijtihad.

There are other fiqh specifications of hirabah, however, such as obstructing free movement of people through the streets (qat'al-tariq), attacks upon pedestrians, and whether attacks are motivated by the purpose of taking money, that have led some fiqh jurists to question the relevance of hirabah for contemporary terrorism. ${ }^{4}$ Certainly, authorities like Imam Malik (d.795/179) and Abu Hanifah (d.767/150) restricted their understanding of hirabah to acts of terror committed in unpopulated and isolated areas, where victims could not call on others for help. This may be tangential to contemporary terrorism. ${ }^{5}$ For instance, if a misguided Muslim youth who, under heavy indoctrination by IS or the Taliban, blows himself up in a densely-populated area in order to kill and destroy, he will neither be after money (but rather "a straight passage to Paradise") nor committing his nefarious acts of terror in an unpopulated area. Even the fiqhi specification that hirabah be committed openly and in defiance of the authorities through the brandishing of weapons and exhibition of overwhelming power to subjugate one's victim may no longer be as relevant to contemporary terrorism; the latter is often committed through hit and run tactics whereby the terrorists do not declare themselves openly, especially in suicide bombings. Thus, it becomes manifest that many of the fiqhi characteristics of hirabah require fresh examination if hirabah is to be made relevant to contemporary terrorism.

Some early commentators argued that the verse on hirabah referred only to Muslim rebels and mutineers, since repentance is normally not accepted from 
unbelievers until they embrace Islam. The majority of jurists, however, have disputed this conclusion, maintaining that hirabah as described in that verse may be committed by anyone, Muslim or non-Muslim, provided that the crime is committed in a territory ruled by a Muslim government. ${ }^{6}$

What remains most relevant about the fiqhi understanding of hirabah is the spreading of fear (ikhafah) and helplessness ('adam al-ghawth). The helplessness aspect means that no effective security measures can be taken against it (ta'adhdhur al-ihtiraz). These are often seen as the constituent elements and sine qua non of hirabah.

Muhammad Rashid Rida (d.1935), the renowned disciple of Muhammad "Abduh, characterised hirabah by saying that, and unlike the other hudud crimes, in which a victim may be able to defend himself, in hirabah he is helpless as he is overwhelmed by a superior force - or else, as we may add now, that the victim is unable to identify his attacker. In other common crimes, the criminal can be subjugated by the authorities. This is not certain in the case of hirabah, which often involves challenging the authority of the government itself. ${ }^{7}$

\section{A Fiqhi Discourse on Hirabah}

Historically, Muslim jurists have been assiduous in trying to protect the Muslim community from those who would seek to harm it through violence and terror. They did so by developing legal constructs based largely on the Qur'anic dispensations concerning hirabah. The resulting laws of hirabah did not remain static, largely due to a degree of flexibility in the Qur'anic expositions, which allowed space for interpretation. Yet the creative endeavours of jurists and interpreters were disrupted by the so-called 'closure of the door of ijtihad' around the fifth/eleventh century. This is partly why a contemporary observer will notice a modern gap in the fighi discourse of hirabah, which is mostly of medieval origin. The narrative we develop in the following pages is therefore self-evidently necessary for the construction of a more relevant understanding of hirabah. This is fortunately possible via a re-reading of the figh discourse in light of the Qur'anic conception of hirabah.

To begin by outlining the fiqhi discourse, the Hanafi jurist, al-Kasani (d.1191/587), defined hirabah (or qat' al-tariq) as "attacks upon pedestrians for the purpose of taking their property by force in such a way that people are rendered unable to pass freely through the streets. The attacker/s may be a group or a single person that possess[es] overwhelming power to obstruct the public passage, and maybe using weapons or weapon-substitutes such as sticks and stones."

The Maliki school defined the agents of hirabah as "anyone who brandishes weapons in order [to] obstruct free passage in the streets rendering them unsafe 
to travel by killing people, taking their money, and spreading corruption in the land. The agent of hirabah/muharib may be a Muslim or a non-Muslim, free or slave, and it may be committed in city or countryside, by an individual or group - simply because the Qur'an has not specified the perpetrator in any such ways."

The Shafi'i school identifies the agents of hirabah in similar terms, but while stressing that the perpetrator must be a competent person (mukallaf) and either a Muslim, a dhimmi or an apostate who is bound by the injunctions of Islam and has overwhelming power to subjugate others and take their money and property in an area away from a main city. ${ }^{10}$

Turning to the Shi'i school, this identifies the agent of hirabah as "anyone who brandishes weapons in order to terrorise passengers during night or day, on land or sea, even if the perpetrator is not a known criminal." ${ }^{11}$ For the Shia, Hirabah is proven by either a valid confession (even if it is not repeated) or by the testimony of two just witnesses - which may include some of the suspects arrested giving testimony against the others. As in Sunni Islam, this is a prescribed/hadd crime and carries a four-fold punishment as specified by the Qur'an (although the Imam is entitled to select which). ${ }^{12}$

The Zahiri school defines the muharib as one/s who insolently frightens the people in the street and spreads corruption through acts of terror, whether in the city or in the countryside, individually or collectively, and while exhibiting overwhelming power with or without the use of weapons. ${ }^{13}$ This may be said to be broad enough to encapsulate many of the points of the other definitions just reviewed.

It will be noted at the outset that the fiqhi discourse on hirabah is focused on the concept's main features and characteristics, rather than on advancing a comprehensive theoretical framework for it. The figh expositions of hirabah revolve around the proper understanding of the principal Qur'anic verse thereon (al-Ma'idah, 5:3) and the application of the four-fold punishment for it - and which depends on the presence or otherwise of killing, of the taking of assets, or on whether or not there was the obstructing of the free movement of people in the streets.

Nevertheless, based on the foregoing, Muslim jurists have held the two main elements of hirabah to be, first, the show of weapons by an assailant/s in order to terrorise people and block their normal movements on public passages and, second, the killing and looting of their property, especially in areas outside the main cities. Hence, if one or two persons were to raid a large caravan, plunder its property and then run away, they would not be committing hirabah, but if they did so against a small caravan manned by a few persons, they would be. Disagreement has arisen over whether hirabah can be committed in urban areas. For Imam Malik, it may because the principal Qur'anic verse on hirabah (as 
reviewed above) is general, without any specification or exception. In this vein, the Maliki school also includes under hirabah any attack on the honour of a people, on their women and families, with the show of superior force. Thus, if armed attacker/s enter another's private dwelling in order to dishonour the victim and his family, and whether the attack occurs within or outside a city, it is hirabah. By contrast, the Hanafi school maintains that hirabah must take place away from the main cities, as within the city areas the public and the police will come to the aid of the victims. Imam Shafi'i has held that an attack in the city can constitute hirabah only if the government/Sultan is weak and lacks effective power. The Hanbali understanding of hirabah resembles that of the Shafi'i's in that it may be committed in both urban and rural areas, with the perpetrator/s armed with any kind of weapon, or anything that may resemble a weapon, provided it can create fear. The Shi' is also regard possession of weapons of any description as a requirement for hirabah. Otherwise, the offence may take place on land or sea, day or night, by one or more persons, provided that the perpetrator/s possess the capacity to terrorise their victim/s. Overall, the majority (jumhur) view is that committing hirabah in cities and urban centres is an aggravating factor that may render the crime even more dangerous. ${ }^{14}$

According to all scholars, for an action to be classed as hirabah it is essential that the assailants are superior in strength, that they carry arms and that their victim/s cannot overpower them or escape. Hirabah must also be committed openly (bi'l-mujaharah). In this respect it differs from theft; if a group of people acted surreptitiously to commit theft or kidnapping, they would fail to fulfil the requirements of mujaharah. Aggravating circumstances consist of taking the victim's property and/or killing them. As is clearly stipulated in the verse under review, repentance by the terrorists before their capture and arrest exonerates them from capital punishment, although it does not necessarily exempt them from criminal responsibility for other crimes committed during the attack (such as homicide, injury and armed robbery). This combines both public and private rights (Haqq Allah and Haqq al-Adami). Hirabah is proven by normal means of evidence, including confession and testimony by impartial witnesses. Confessions may be made only once and not repeated. ${ }^{15}$

The Hanafis are in the minority when stipulating that bandits must be men; Imam Abu Hanifah and his disciple al-Shaybani hold that women are not punishable by the prescribed punishments if they perpetrate hirabah. This is because the necessary show of power and strength is only suited to men. Another of Abu Hanifah's disciples, however, Abu Yusuf, held that if any woman was directly involved in killing and plundering, they would also be liable for punishment together with men. Likewise, the Maliki, Shafi'i, Hanbali and Shia schools do not regard male gender as a prerequisite for hirabah. Thus, if women 
commit banditry in groups that terrorise people and obstruct the highway, they are liable to the same prescribed punishments as men. ${ }^{16}$

\section{Punishment of Hirabah}

For the prescribed punishments to be carried out, the perpetrators must be competent adults, for this is the precondition of all the hudud punishments. There is disagreement, however, concerning whether a child or an insane person who participates in hirabah as part of a larger group is also liable for punishment. The majority hold that the prescribed punishment will apply to them, for any doubt attached to one member of the group should not come in the way of enforcing the punishment. A comparable case here would be when a group of persons commit zina with one woman; all of them are punishable. The Hanafi school, however, differs on this perspective. It regards the participation of a child in hirabah as an element of doubt (shubha) that suspends the prescribed punishment on all participants - although they may still be punished under ta'zir. Nevertheless, Abu Yusuf has held that if the competent persons among the group carried out the actual crime of hirabah, they are liable to the punishment while the child will not be. ${ }^{17}$

As mentioned, the Qur'an provides a four-fold punishment for hirabah, namely execution, crucifixion, cross-amputation and banishment. There is disagreement over the choice of these punishments. While the majority of Sunni schools and the Shia authorise the ruler to select one or more of these punishments in proportion to the severity of the crime, Imam Malik held that, if the assailants killed their victim, the imam/judge had no choice but to order capital punishment. The only choice he would have is whether or not to combine crucifixion with execution. Likewise, if property (of whatever value) had been taken, Malik held that the offender/s must be punished with at least cross-amputation. If there had been a hold-up, the offender must be sentenced to mutilation and/or banishment. The other Sunni schools, however, and in addition to one view from the Shia Imamiyyah, attributed to Shaykh Tusi, hold that the Qur'an has provided a correlation between a crime and its punishment which authorities should observe. In their view, an offender/s is not killed if he has not committed homicide and not mutilated nor banished unless property is taken. ${ }^{18}$ Finally, if an assailant has both plundered and killed, his punishment should be both death and crucifixion. A group of Muslim jurists, however, and including some from the Shia, give rulers/imams discretion over the selection of an appropriate punishment or combination thereof, regardless of whether or not homicide and/or robbery has been committed. Disagreement has also arisen over whether crucifixion should be before or after execution. While some argue that crucifixion can only be 
regarded as a punishment when the criminal is still alive, others have held that the Qur' anic text mentions killing first, then crucifixion, and that should be the order. The Hanafis and some other jurists have, furthermore, equated banishment with imprisonment on the analysis that banishment to another place will put the safety of those other people at risk, entailing that the purpose of banishment would be better served by imprisonment. ${ }^{19}$

A question has arisen as to whether the hadd punishment for hirabah combines with liability for financial compensation and bodily injuries, even after the bandits have been punished. Muslim jurists have differed in their responses to this issue. According to the Hanafis, hadd punishment does not combine with liability for loss. Most Sunni and Shia jurists, however, have tended to separate the hadd of hirabah from financial compensation. The majority view is therefore that, if bandits have plundered property, they are liable to either return it if it still exists, or else compensate for its loss. Many jurists have also held that only those who have actually taken the property are individually liable to pay compensation, as liability for compensation is not part of the hadd penalty per se and so cannot affect someone who is not directly involved. The Malikis, however, have held that each bandit acted on behalf of the group, making all liable for paying compensation. As for bodily injuries, if the injured person has recovered there is no retaliation (qisas). If not, however, he or she may either retaliate (if that is possible) or else grant forgiveness in exchange for financial compensation. However, if the injury has worsened and leads to death, then retaliation becomes due. The Zahiri school has held, on the other hand, that the crime of hirabah is committed by causing bodily injury only, even if there is no killing or plunder involved, and the bandits are therefore liable to the capital hadd punishment. ${ }^{20}$

The majority of Sunni schools in addition to the Shia maintain that any killings perpetrated by the bandits need no proof of intention, the act of killing itself making them liable to the prescribed punishment. It makes no difference whether the homicide so committed was intentional, quasi-intentional or erroneous. It is also immaterial as to what kind of weapons were used to commit the crime. The Shafi'i school, however, maintains that proof of intention to kill is required for the imposition of the prescribed punishment, although the terroristic features of the crime of banditry need no proof of intention as it is clearly demonstrated by the show of force intended to strike fear amongst the people. ${ }^{21}$

Fresh reflection on the conditions and component elements that Muslim jurists have stipulated during their expositions of hirabah suggest that, although undoubtedly instructive, changes are required if one is to legislate on terrorism today. For example, today most terrorists tend to use remote controlled devices connected to devastating explosives. As a result, the terrorists themselves may or may not be actually present at the crime scene. Likewise, terrorist groups may 
(and often do) use children as suicide bombers, and therefore again be absent themselves from the scene. Other aspects of hirabah, such as the requirement that there be a group of persons, may also require further reflection and review. Certainly, the Qur'an determines the crime of hirabah by its consequences: waging war against society and spreading mischief (terror, insecurity and destruction) in the land. It does not specify any other detail, such as the number of people involved. It merely lays down the essential elements of the crime, which is perhaps sufficient for contemporary rulers and legislative authorities to determine the component elements of hirabah in the light of prevailing conditions.

\section{Repentance in Hirabah}

As for the attributes of the repentance that suspends the capital punishment and its consequences, Muslim jurists have held different views. It has been suggested that repentance is only valid if the offenders abandon what they were doing and surrender to the authorities before they are overpowered by the latter, not afterwards. It is further suggested that, even if the assailants surrender, they must still show that they have actually mended their ways, specifically by disarming and abandoning what they were doing. Only then can the prescribed hadd punishment be suspended. Muslim jurists have also differed as to the consequences of repentance: does it suspend both God's Right and the Right of Humans and, if so, which takes precedence and in what proportion? In response, the Maliki opinion is that repentance before arrest only suspends the capital punishment of hirabah, nothing else. All other claims, and in both categories, remain unaffected. This means that the authorities may impose alternative punishments and the individual/s affected remain entitled to claim their rights in whatever way they may, and unless they choose to grant forgiveness. The Shafi'i school maintains that the Right of Man takes priority: if homicide or bodily injury has been committed during a hold-up, the crime must be tried first according to the relevant rules. This view has the support of the other schools, in that an assailant is not exonerated for homicide and bodily injury due to repentance or surrender. If, however, the victims' relative/s grant forgiveness or accept bloodmoney, and the authorities also grant pardon, action may be suspended against the bandits. An alternative view has it that repentance suspends both of the said categories of rights, except for any property that may still exist and which must be returned. It would appear that the Imam and/or judicial authorities have residual jurisdiction in regard to determining the precise consequences of a genuine repentance and surrender. ${ }^{22}$

A quick perusal of the Qur'an shows that spreading mischief/corruption in the earth is a major theme, occurring in a large number of places. Included under 
fasad fi'l-ard are: spreading of heresies (Q 2:11-12), destruction of the living environment (30:41), destruction of farmland, gardens and waterways (26:141f), persistent criminality $(5: 32)$, inciting enmity and hatred among the people $(5: 64)$, practicing and spreading sorcery (10:79), humiliating people through Pharisaic absolutism (28:4), practice and incitement to sodomy and homosexuality (29:28), killing and brutalising innocent people (2:30), and persistent hypocrisy (2:204).

After discussing the Qur'anic passages on fasad fi'l-ard, al-Khattaf observed that the concept is broad enough to subsume such contemporary criminal activities as drug trafficking, human trafficking, Mafia-like crime syndicates, and loan sharks who kidnap people, destroy and brutalise them and their families. Additionally, it could also cover armed rebellion and military coups that topple lawfully elected governments. To quote al-Khattaf:

This is why hirabah acquires enormous significance in our lives today, especially after what we witnessed in the Arab region through the so-called Arab Spring; the inciters to violence and war that invaded peoples' lives and properties, wreaked havoc on them and the lives of entire communities and their homelands...The Qur'anic concept of 'spreading mischief in the earth' also includes the agents of corruption who shake the constitutional order, play with peoples' lives and collude with enemies to carry out their sinister designs. ${ }^{23}$

The contemporary relevance of hirabah and the clear scriptural grounding it has in the Shariah can hardly be underestimated in the light of the horrendous atrocities that people have been subjected to by bandits, warlords, drug barons and other criminals in war-torn Syria, Iraq, Afghanistan, Nigeria, Somalia and elsewhere. This is not to mention those who have terrorised innocent civilians, women and children, committing genocide and other crimes against humanity in the name of a caliphate. There is absolutely no room in the Shariah for such atrocities, whether by IS, al-Qaeda, the Taliban, al-Shabab, Boko Haram or others. Justice must be served and the truth uncovered and told. Although amnesty can be granted to some in the hope of a peaceful end to hostilities, those criminals who have committed the most nefarious atrocities and crimes against humanity must face their punishment. Only then can one nurture any realistic prospect of a peaceful future for affected individuals and their communities.

\section{Terrorism Then and Now: A Survey of Contemporary Opinion and Research}

Terrorism is not a new phenomenon, although certain forms of it may be unprecedented. In one form or another terrorism has occurred throughout history, 
and whether committed by individuals or groups. Instances of targeted killings, for example, are known from Medieval Muslim history, when Ismaili "Assassins" based in al-Alamut assassinated prominent Muslims like Nizam al-Mulk. During the $19^{\text {th }}$ century, terrorism was practiced by Russian anarchists, while the $20^{\text {th }}$ century saw large-scale Bolshevik State terror, in addition to terrorism exercised by nationalist movements like the IRA, the Zionist Stern Gang, and the Armenian Nationalists. Each of these groups considered terrorism to be a cost-efficient and effective form of warfare for the poor that would put public pressure on governments to change their policies. In most cases, however, their terrorism was counter-productive: "Virtually nowhere has terrorism produced the desired result. Rather in most cases, it has stiffened resistance and caused untold suffering to friends and foes alike." 24

In a book chapter entitled "The Revolt of Islam 1700 to 1993," Nikkie Kiddie, an American professor of Middle Eastern history, explains the rise of militancy among Muslims. She notes that, with the curious exception of Wahhabism, modern militant jihadi movements mostly began and grew up as a response to Western colonialism. The earliest, founded during the $18^{\text {th }}$ century in Sumatra and West Africa, emerged in the face of "disruptive economic change influenced by the West." In the nineteenth century, broader waves of jihadi movements cropped up in Algeria, Sudan, the Caucasus, and Libya as "a direct response to French, British, Russian and Italian colonial conquest." 25

A variety of historical and ideological causes have contributed to the growth of terrorism. As is well known, gold and glory were the most obvious motivations behind the European colonial project and which led to the occupation of Latin America, parts of Africa and Asia and the foundation of various terrorist movements. Both World Wars, in addition to the Korean and Vietnam wars, were primarily attributable to ideological causes. The Balkan tragedy was essentially based on ethnic and religious grounds. The mass genocide in the Christian-majority state of Rwanda was largely motivated by tribalism, whereas the Ugandan civil war was primarily due to Christian religious radicalism. The mass killings of Muslims in the Ivory Coast by Christian and indigenous groups were ethnically and religiously motivated. The decades-old Sri Lankan civil war between Hindu-Tamil separatist groups and the Buddhist-Sinhalese majority was also based on ethnic and religious factors. ${ }^{26}$

At a press interview entitled "There is nothing in Islam that is more violent than Christianity," Karen Armstrong replied to questions put to her by Lisette Thooft about Islam and terrorism. ${ }^{27}$ When replying to a question about the causes of Muslim terrorism, Armstrong highlighted the manner in which the Western world imposed its own concepts of modernity, democracy and secularism on the Muslim world through colonial subjugation. "There was no self-determination. 
In Egypt there were 17 general elections between 1922 and 1952 - all won by the Wafd Party, which was only allowed by the British to rule five times. Democracy was a bad joke." Secularism, she said, was violently introduced by army officers. At the same time, members of the Muslim clergy had their stipends confiscated, were shot down and tortured to death. In Iran, the Shah shot one hundred unarmed demonstrators at a holy shrine because they didn't want to wear western clothing. Moreover, Armstrong pointed out how "we in the West" have consistently supported rulers like Saddam Hussein, who have consistently denied their people any freedom of expression. All this has helped to push Muslims towards violence: "When people are attacked, they invariably become extreme." But only a tiny proportion of them actually agree with terrorism: $93 \%$ of Muslims answered 'no' during a Gallup poll when asked whether the 9/11 attacks were justified.

When asked whether terrorists are traumatised, Armstrong replied that:

Some of them are, and some of them are plain wicked. Osama bin Laden was a plain criminal. But there is also great fear and despair among them. There have been surveys done by forensic psychiatrists who interviewed people convicted of terrorism since 9/11. They interviewed hundreds of people in Guantanamo and other prisons. And one forensic psychiatrist, who is also an officer of the CIA, concluded that Islam had nothing to do with it. The problem was rather ignorance of Islam. Had they had a proper Muslim education they wouldn't be doing this. Only $20 \%$ of them has had a regular Muslim upbringing. The rest are either new converts - like the gunmen who recently attacked the Canadian Parliament; or non-observant, which means they don't go to the mosque - like the bombers in the Boston marathon; or self-taught. The two young men, both 22, who before leaving Britain to join the jihad in Syria, ordered from Amazon copies of Islam for Dummies, and The Koran for Dummies. Furthermore, tedium is something that we have to take in our societies seriously. Misery and a sense of no hope. Misery, oppression and injustice - great injustice and we are still unjust. Look at the Founding Fathers of the United States, who said that all men are created equal: they had no problem owning African slaves. Liberty was only for Europeans. And it still is like that. Because of the greed for oil, we give huge support to the Saudis, who give their people no human rights.

American political scientist Steven Fish, in his book Are Muslims Distinctive?, found no evidence that countries with a larger share of Muslims experience a disproportionate number of acts of mass political violence. He notes, in fact, and 
as Saleena Saleem reviews him, that when it comes to violent crimes such as murder, Muslim majority countries have consistently lower rates when compared to Christian majority countries. Such facts, however, get lost when the focus is on those Muslim extremists who commit the majority of violent political and terrorist acts on a global scale. As for the role of religion, it is further noted that violent upheavals in the Middle East are primarily driven by regional political interests rather than Islam..$^{28}$

Regarding young French jihadists, Fareed Zakaria observes that most have no background in political activism, fundamentalist Islam or social conservatism. Quoting the French scholar Oliver Roy, Zakaria states that radicalisation in France tends to arise around a fantasy of heroism, violence and death, not the shahadah or a promised utopia. Abdelhamid Abaaoud, the ringleader of the Paris attacks, regularly used drugs and drank alcohol, as did many of his comradesin-arms. Today the decision to join IS is usually sudden and impulsive; IS is the ultimate 'gang', celebrating violence for its own sake. Moreover, many of these young men - and some women - are second-generation Europeans revolting against their more traditional, devout immigrant parents. ${ }^{29}$ These people are unsure of their identity, rooted in neither the old country nor the new. They face discrimination and exclusion. And in this context they choose a life of rebellion, crime, and then the ultimate adventure, jihad.

These circumstances also explain why Belgian Muslims make up a disproportionate share of IS volunteers. Fifteen percent of native-born Belgians live below the poverty line, compared to a staggering half of all Belgians with a Moroccan background. In addition, Belgium has a poor record of assimilation, largely because of its own identity crisis, torn between Flemish and Walloon cultures.

All of the above paints a picture of a new kind of terrorist, one who is less drawn to terrorism because of religion and more because of a need to rebel. This does not absolve Muslims, however, of their duty to eradicate the cancer in their midst - that is, radical Islam. As for Western law enforcement, it also suggests that bugging mosques, patrolling Muslim community centres and the like, might be focusing attention in the wrong direction. Potential terrorists might instead be found in bars, drug alleys, unemployment lines and prisons, getting radicalised before they get Islamised. ${ }^{30}$

Terrorism is evidently not a monolithic category and has developed in new directions over time. Looking at the regional and geographical manifestations of terrorism, Azhari Karim explains: Whereas al-Qaeda and more recently the IS group are seen to be accountable for much of the terrorist attacks in Europe (Paris, Nice and Brussels) and the United States (san Bernadino and Orlando), the majority of incidents seem to have been by individuals who acted alone. ${ }^{31}$ 
However, from Libya, Tunisia, Egypt, Sudan, and Somalia to Afghanistan, Pakistan, Yemen, Iraq, Turkey, Syria and Saudi Arabia, groups such as al-Qaeda, the Taliban, Houthis, and Nusrah al-Qudra have fought wars with local authorities as a means of settling old "scores" with corrupt government officials and states that are seen as overly dependent on the West for their survival. Elsewhere, there are 'clones' of such radicalised and irredentist movements in the Ukraine (proRussians), China (Uighurs) and Nigeria (Boko Haram), as well as in parts of South America (Columbia, Peru and Brazil). Their aims have centred on a need for change and transformation, with economic development and social progress at the top of their agenda. Things are not the same in the Israeli-occupied Palestinian Territories, however, or in the countries of South and Southeast Asia, where some have resorted to violence in order to draw attention to local, "nationalist" problems. In Southern Thailand (Patani United Liberation Organisation) and the Philippines (Abu Sayyaf), for example, terrorist groups have been motivated by the struggle for autonomy and self-rule.

Only in the triangle of countries that includes Malaysia, the Philippines and Indonesia, do we note IS or al-Qaeda-type groups whose sole purpose is to bring about a new "Islamic Order" or "New Caliphate." Groups such as Jemaah Islamiyyah, al-Mauunah and Abu Sayyaf have not only resorted to kidnapping and ransom-taking, but also to inflicting gross violence against local governments and populations..$^{32}$

Across the Muslim world, radicalisation by external forces has been identified as the principal means by which terrorist groups seek recruits. As well as "returnees" from the battlefronts of Iraq and Syria, who come home and spread radical messages, various IS-based social media postings help to gather recruits. Another new development and potential source of recruitment has been the 2016 United States presidential election campaign. The Republican nominee, and now President, Donald Trump made the restriction of immigration, especially of Muslims from the Middle East, a campaign promise, subsequently backing it up with several (unsuccessful) travel bans once he reached office. These developments are likely to provide terrorist groups with additional weapons with which to intensify their propaganda assaults and win over new, impressionable Muslim recruits to their side.

An added complexity to this scenario has been the 2015-2016 waves of mass Muslim migration into Germany and other European countries. As large numbers of young migrants from war-torn areas in Syria, Iraq and Afghanistan enter Europe, instances of crime and terrorist attacks have increased (such as the July 142016 Nice truck attack in France, which killed 86 people, in addition to lesser incidents in Germany and Belgium). According to Peter Apps, "it became increasingly less relevant whether an attack - such as the gun attack in Munich 
which killed nine, or the stabbing of an orthodox Jew in France, or a machete attack on a bus in Brussels - is directly related to a militant group like IS or not; provided a migrant or someone of migrant descent is involved, it all falls into the same divisive narrative." ${ }^{\prime 3}$ In many ways, what happened on the beach at Nice is exactly what groups like IS want: acts that will deepen divisions within society.

Dealing with terrorists also poses various legal challenges, with practices differing in different countries. In France, for example, one cannot detain a terrorist suspect unless they are caught in the act or there is strong evidence suggestive of a conspiracy. In the US, on the other hand, a suspect can be detained on the basis of evidence received from other countries. The problem revolves around security and human rights issues. Admittedly, countries can devise their own approaches, and many countries have, in fact, proposed or passed new antiterrorism laws according to their own needs.

\section{Suicide and Suicide Bombings}

Suicide falls under the Qur'anic provision of 'killing without just cause' (illa bi'l-haqq al-Isra' 17:33), since a person does not have the right to take his/her own life. Since life is a God-given gift, it may not be subjected to destruction and abuse, even by its owner. This is why the Shariah forbids suicide without exception. It is a heinous sin for which the perpetrator is liable, in the event of an unsuccessful attempt, to a deterrent penalty of ta 'zir. If the attempt succeeds, the person is still liable to an expiation (kaffarah) which may be taken from his property (according to the Shafi'is and some Hanbalis; the Hanifis and Malikis do not make kaffarah a requirement). ${ }^{34}$ The Qur'anic authority on this is: "Kill yourselves not, for God is truly Merciful unto you" (al-Nisa', 4:29).

Life is a trust (amanah) in the hands of its bearer, who is expected to safeguard and cherish it with responsibility and care. People who are driven to despair are advised to have faith in God's mercy and remain hopeful (al-Zumar, 39:51). The prohibition against suicide also means that anyone who facilitates or collaborates in it is also liable to a deterrent punishment. ${ }^{35}$

Qur'anic commentators and jurists have drawn the following conclusions from verse 4:29, cited above:

- The obvious meaning is that suicide is forbidden.

- The verse also means that 'you may not kill one another.'

- No one should deprive himself of the essentials of life, lest doing so lead to death.

- One may not indulge in self-destructive crimes and consumption of lethal substances. ${ }^{36}$ 
The Prophet has spoken strongly in condemnation of suicide, as in the following hadith:

The one who throws himself off a mountain cliff and kills himself will be doing the same to himself perpetually in Hell. The one who takes poison and kills himself shall be holding the same in his hand and permanently taking it in Hell, and the one who kills himself with a weapon will be piercing his body with it perpetually in Hell. ${ }^{37}$

A similar hadith proclaims that the "one who kills himself with something in this life will also be tortured by it on the Day of Resurrection." 38

Al-Bukhari has recorded a long hadith in which the Prophet is said to have seen a man during a battle against the pagans. Although this man was by all accounts one of the most capable of all the Muslim warriors, the Prophet said the following concerning him:

"One who wants to look at someone from the inhabitants of Helllet him look at this man." Another man followed him and kept on following him until the fighter was injured, and in a wish to die quickly, he placed the tip of his sword on his breast and leaned over it until it passed through his shoulders and [he] died." ${ }^{\text {39 }}$

\section{Muslim Responses to Terrorism}

The upsurge in suicide bombings by those who claim to be Islamic warriors has brought a mixed response from Muslim scholars. Most scholars of standing have not hesitated to condemn them as contrary to Islamic principles. For example, the Jeddah-based Islamic Fiqh Academy, which is affiliated to the Organisation of Islamic Conference (OIC - now Cooperation), in its sixteenth session (5-10 January 2002) condemned all forms of terrorism:

Terrorism is an outrageous attack carried out either by individuals, groups, or states against the human beings. It includes all forms of intimidation, harm, threats, killing without a just cause, all forms of armed robbery, banditry, every act of violence or threat intended to fulfil a criminal scheme individually or collectively, terrify and horrify people by hurting them or by exposing their lives, liberty and security to danger. It can also take the form of inflicting damage on the environment, a public or private utility - all of which are resolutely forbidden in Islam. ${ }^{40}$ 
In November 2003, the Arab states condemned a suicide car bombing in Riyadh that killed 17 and wounded more than a hundred. The 22-member Arab League denounced the attack as "terrorist and criminal," while Saudi Arabia and its five neighbours in the Gulf Cooperation Council condemned it as "cowardly and terrorist." The then Arab League secretary-general, Amar Musa, also said such acts "only aim[ed] to destabilise...terrify and kill" innocent people. ${ }^{41}$

More recently, Muslim religious and political notables have expressed unqualified condemnation of the IS group and incidents such as the Charlie Hebdo atrocities. Muslim international organisations and fatwa councils, including the Majlis Ulama Indonesia, the National Fatwa Council of Malaysia, and the Mufti of Saudi Arabia, have denounced the brutality and violence of IS as a violation of the core principles of Islam.

Abusive interpretations of jihad notwithstanding, jihad is primarily an instrument of peaceful self-education and improvement. The pathways to peace in Islam are also enriched by its teachings on human fraternity, compassion, honouring one's neighbour, avoiding harm to others, as well as its rich tradition of Sufism. Islam also advocates peace through non-violence, universalism and a generally positive view of human nature and potential.

Mahmud Shaltut, the Shaykh of al-Azhar University from 1958 to 1963, lends considerable weight to the argument that the Qur'an only allows war in self-defence, quoting numerous verses from the Qur'an (including al-Anfal, 8:61; Mumtahanah, 60:8-9; al-Baqarah, 2:190 and al-Hajj, 22:39-40) which uphold that principle. ${ }^{42}$

Another Shaykh of al-Azhar, Muhammad Sayyid Tantawi, issued a fatwa in 2001 condemning the hostage-taking in the Philippines: "Islam rejects all forms of violence. These acts of violence have nothing to do with Islam." ${ }^{43} \mathrm{He}$ also condemned September 11, 2001. ${ }^{44}$ The Chief Mufti of Saudi Arabia, Abdulaziz bin Abdullah al-Shaykh, also declared in 2004 that:

You must know Islam's firm position against all these terrible crimes. The world must know that Islam is a religion of peace, justice and guidance...Islam forbids the high jacking of airplanes, ships and other means of transport, and it forbids all acts that undermine the security of the innocent. ${ }^{45}$

The Washington-based Fiqh Council of North America (FCNA) issued the following fatwa and press release on July 29, 2005:

Islam strictly condemns religious extremism and the use of violence against innocent lives. There is no justification in Islam for extremism or terrorism. Targeting civilians' life and property through suicide bombings or any other method of attack is haram - forbidden - and 
those who commit these barbaric acts are criminals, not 'martyrs'...We clearly and strongly state: 1) All acts of terrorism targeting civilians are haram. 2) It is haram for a Muslim to cooperate with any individual or group that is involved in any act of terrorism or violence. 3) It is the civic and religious duty of Muslims to cooperate with law enforcement authorities to protect the lives of all civilians. ${ }^{46}$

Judging by the scale of violence that recent years have witnessed in Afghanistan, Iraq, Syria, Palestine, and elsewhere, Muslims are themselves the principal victims of terrorism, women and children in particular.

But unless the root causes of extremism are addressed, many have warned that extremism and violence are likely to increase. Once a radical group falls by the wayside, discredited or made irrelevant, others, often more radical and violent than the last tend to emerge. Certainly, this is evident with IS and alQaeda, the former upping the stakes in the radicalisation contest by becoming even more destructive and violent than its predecessor. ${ }^{47}$ Unless the legitimate claims of those who suffer from oppression and injustice are heard, angry and disillusioned men and women, Shia, Sunni, Kurds and others, will feel that the path to violence is the only one left to them. ${ }^{48}$

In 2012, Mark Winer wrote in an article entitled "Fundamentalists versus Moderates" that the future of humanity may well depend on the ability of religious moderates to overcome their extremist co-religionists. Extremism, he argued, only spawns interfaith bigotry while sanctioning violence, war and terrorism. A great deal therefore depends on our understanding of the eternal conflict between extremism and moderation, and on the strategies religious moderates devise to combat this common scourge. ${ }^{49}$

It is indicative of the wisdom of the early Muslims that they labelled a group which behaved similarly to modern-day terrorists as 'Kharijites' (Khawarij, lit. outsiders). By this name they made it known that this group had exited itself from the mainstream community, thereby giving them the choice of either changing their behaviour and re-joining the community or else staying as outsiders. The same can be said of ghulat (lit. exaggerators), the name so unmistakeably expressive of its purpose, that was given to a small group of Shia who exaggerated their interpretation of the doctrine of imamate so as to elevate the first Shi' ite Imam, 'Ali ibn Abu Talib, to a deity.

One can hardly think that anyone could soil Islam's name as badly as the likes of IS, Boko Haram and al-Shabab have done. If the militants should even realise this, that they are doing more harm than good in the cause of their religion, "as Islamic leaders all over the world are already pointing out, their numbers will eventually diminish." 50 


\section{Conclusion and Recommendations}

This article explored the shariah resources on hirabah and sought to adjust some of the fiqhi articulations of this crime in light of contemporary developments. It also explored the commonalities and differences between hirabah and contemporary terrorism. In its quest to construct a more contemporary reading of hirabah, it sought to refer some of the restrictive articulations found in the figh sources back to their roots in the Qur'an. A direct recourse to the broader Qur'anic conception of hirabah has been instrumental in providing relevant responses to contemporary questions. It is hoped that other researchers will continue to address the relevant issues and further explore the shariah resources. Although the Qur'an is the most authoritative source in the context of this endeavour, the Sunnah of the Prophet and the legal maxims of fiqh are also instructive.

For example, one of the most important concepts in the hadith, and which is also expounded in a number of leading fiqhi maxims, is the prevention and elimination of harm - or the principle of la-darar. The principal hadith on this simply declares that "Harm may not be inflicted nor reciprocated in (the name of) Islam [la darar wa la dirar fi'l-Islam]." This hadith has in turn been adopted as a legal maxim, with a number of other maxims providing instruction on many other aspects of darar. All of these can be utilised to provide additional and supplementary material to the Qur'anic dispensations on hirabah, and may even prove to be of greater utility in the hands of lawyers and judges who seek to provide legal remedy for the loss and damage caused by the perpetrators, organisers and sponsors of hirabah. We quote, in bare skeleton form, some of the supplementary legal maxims on darar as follows:

- 'Harm must be eliminated/removed [al-dararu yuzal].'

- 'Harm may not be eliminated by its equivalent [al-dararu la yuzalu bimithlih].'

- 'Harm is to be prevented/removed as far as possible [al-dararu yudfa' $u$ bi-qadr al-imkan].'

- A specific harm is tolerated in order to prevent a more general one [yutahammal al-darar al-khass li-daf' al-darar al-'aam].'

- 'A greater harm is eliminated by tolerating a lesser harm [al-darar alashadd yuzal bi'l-darar al-akhaff].'

- 'Harm does not establish a precedent [al-dararu la-yakunu qadiman]. ${ }^{51}$

Finally, we conclude this article with a set of actionable policy recommendations:

- Terrorism has become a global and exceedingly diverse phenomenon, such that no single country or community can address or eradicate it alone. Combating global terrorism requires collective action by all concerned parties. 
- Islam is a religion of peace, as attested to by the fact that the Qur'an punishes all acts of terror designed to disrupt normal life, peace and order in the community.

- The Qur' an designates the agents of hirabah as those who wreak corruption in the earth and wage 'war on God and His Messenger.'

- Islamic groups, including the religion's religious and political leaders, have vehemently denounced terrorism and issued verdicts and fatwas prohibiting it. Terrorism is therefore forbidden in all its forms, whether it is committed by individuals or states and regardless of the gender, race and religion of its perpetrators. It is a crime and can never be justified in the name of Islam.

- Extremism and terrorism can be contained and defeated only in the hearts and minds of the people. The ulama, in addition to mosque and community leaders, should therefore make the rejection of terrorism a priority in their teachings, thereby effectively combating it.

- Muslim government leaders should work more closely with community leaders, religious institutions, education centres and the media in order to create an anti-extremist current of opinion.

- Muslim leaders and governments should explore all peaceful approaches towards the resolution of conflicts among Muslims, but without compromising on the essentials of justice and on the rule of law.

- Muslim countries should take control of their own affairs and not expect foreign parties to resolve their disputes. This does not, however, mean that genuine cooperation with outside parties should be discouraged.

- Good governance, respect for the rule of law and a resolute campaign against official corruption can go a long way toward earning people's trust and enhancing the ability of governments to work effectively for the peaceful settlement of disputes.

- A constitution that is cognisant of the essentials of Islam, enacted through consultative methods and promulgated by the lawfully designated leader of a country (ahkam ul'il-amr), inspires obedience. Religious leaders should accordingly play a proactive role in the realisation of a law-abiding society and due enforcement of the constitution.

- If governments focus on economic development, job creation, social justice and improving quality of life for vulnerable groups, they will help nullify the strongest causes of extremism in the Muslim world.

- Due to their positions within their families, women can exert a stabilising influence on society and on the youth. Muslims should strengthen and elevate the status of women, enlisting their support in the cause of peace.

- All acts of provocation by state actors and institutions, including 
interference in the affairs of other communities and states, indiscriminate drone attacks, aggressive action, and policies that exacerbate existing conflicts and threaten peace and security, should be stopped.

- Those who offend in the name of freedom of expression, particularly at sensitive times, are not helping the cause of peace or freedom and should restrain themselves. If anyone benefits from persistent cartoonist provocations, it is the terrorists.

- When dealing with instances of violent extremism, states and security forces should avoid the trap of reacting to violence with greater violence. Doing otherwise will likely mean an even greater victory for the terrorists.

- Muslim countries should continue to base their relations with the outside world on positive foundations, particularly the principle of constructive cooperation in combating international terrorism.

\section{Notes}

* Mohammad Hashim Kamali, Founding CEO of IAIS Malaysia, graduated from Kabul University, and then obtained his $\mathrm{PhD}$ in Islamic and Middle Eastern Law at the University of London in 1976. He served as Professor of Islamic Law and Jurisprudence at the International Islamic University Malaysia (1985-2004), then Dean of the International Institute of Islamic Thought and Civilization (ISTAC) from 2004-2006. He was Asst Professor at McGill University's Institute of Islamic Studies; Visiting Professor at Capital University, Ohio; and the Wissenschaftskolleg, Berlin. He was a member of the Constitution Review Commission of Afghanistan (2003), and a UN shariah expert on the constitutions of Iraq, the Maldives and Somalia (2004-2005). He has published over 200 academic articles and 35 books. He can be contacted at ceo@iais.org.my.

1. Sherman A Jackson, 'Domestic Terrorism in the Islamic Legal Tradition,' The Muslim World 91, no. 3 \& 4. (2001): 293-310.

2. Muhammad b Ali al-Shawkani, Fath al-Qadir (Damascus: Dar al-Kalim alTayyib), Vol. 2, 39.

3. See for details Hasan al-Khattaf, Mafhum al-hirabah wa dawabituha: Dirasah bayn al-nass al-Qur'ani wa'l-turath al-fiqhi, Islamiyyat al-Ma'rifah: Majallat al-Fikr al-Islami al-Mu'asir (Herndon: VA, 2015/1436), Vol. 21, 11 \& 42.

4. Ibn Qudamah (d. 1223/620) defined hirabah as "the act of openly holding people up in the desert with weapons in order to take their money." Ibn Qudamah, $\mathrm{Al}$ Mughni, (Beirut: Dar al-Kutub al-'Ilmiyyah, n.d.), 315.

5. Ibid., 303.

6. Muhammad Rashid Rida, Tafsir al-Manar, 94.

7. Ibid., 93 .

8. 'Alauddin al-Kasani, Bada'i' al-Sana'i fi Tartib al-Shara'i' (Beirut: Dar alKutub al-'Ilmiyyah, 1997), 7.

9. Sayyid al-Sabiq, Fiqh al-Sunnah (Dar al-Fath li'l-A'lam al-'Arabi, 1999), 2/298; 
Ibn 'Abd al-Barr, al-Kafi fi Fiqh al-Madinah al-Maliki (Beirut: Dar al-Kitab al'Ilmiyyah, 1997), 582-3.

10. Muhammad al-Shabini al-Khatib, Mughni al-Muhtaj ila-Ma'rifat Ma'ani alMinhaj (Cairo: Mustafa al-Babi al-Halabi, 1933), 4/180.

11. Muhaqqiq Hilli, Mokhtasar-e Nafi, trans. Muhammad Taqi Daneshpazhoh (Tehran: Bongah-e Tarjoma wa Nashr-e Kitab, 1343), 365.

12. Ibid. Other details over the enforcement of punishment (including crucifixion) and repentance etc. do not differ significantly from the Sunni expositions of the same.

13. Ibn Hazam al-Zahiri, al-Muhalla (Beirut: Dar al-Afaq, n.d) vol. 11, 306.

14. Al-Mawsu'ah al-Fiqhiyyah, Hirabah, Vol. 17, 157; Ibn Qudamah, al-Mughni, Vol. 8, 287; Muntasir Saeed Hamudah, al-Irhab: Dirasah Fiqhiyyah fi'l-Tashri' al-Jina'i al-Islami (Alexandria: Dar al-Jami'ah al-Jadidah li'l-Nashr, 2008),74; Mohaqqiq Hilli, Mokhtasar-e Nafi', 365.

15. Al-Qurtubi, Bidayat al-Mujtahid, II, 340-1; al-Mawsu'ah al-Fiqhiyyah (Kuwait), Hirabah, 153 \& 158; 'Awdah, al-Tashri' al-Jina'i al-Islami, II, 657; Mohaqqiq Hilli, Mokhtasar-e Nafi', 365.

16. Al-Kasani, Bada 'i' al-Sana 'i', Vol. 7, 91; al-Mawsu'ah al-Fiqhiyyah (Kuwait), Vol. 17, Hirabah, 156-7.

17. Mawsu'ah Fiqhiyyah, (Kuwait) Hirabah," Vol. 17, 156.

18. 'Awdah, al-Tashri', Vol. 2, 645; Mohaqqiq Hilli, Mokhtasar-e Nafi', 365. If the bandits have taken property, the property in question must qualify as stolen goods (i.e. that it has market value, reaches the minimum quorum, and is also guarded property in which the taker has no share or claim of ownership). Unlike in theft, however, it may have been taken openly, even with the knowledge of its rightful owner.

19. Al-Qurtubi, Bidayah, II, 341; Awdah, al-Tashri', II, 658-59.

20. Al-Kasani, Bada'i', Vol. 7, 95; Mawsu'ah Fiqhiyyah, Hirabah, vol. 17, 162; 'Awdah, al-Tashri', II, 658-9.

21. Ibn Qudamah, al-Mughni, Vol. 10, 309; 'Abd al-Qādir 'Awdah, al Tashri' alJina 'i al-Islami (Beirut: Dār al-Kitab al-'Arabi), n.d., vol. II, 657.

22. Al-Qurtubi, Bidayat al-Mujtahid, 342-3; Peters, Crime and Punishment in Islamic Law, 59. See also 'Awdah, al-Tashri', II, 658-61.

23. Al-Khattaf, Mafhum al-Hirabah, 12.

24. Murad Wilfred Hofmann, "Fanaticism, Extremism and Terrorism and Islam's Position Towards these Phenomena," conference paper presented at the International conference in Amman on "True Islam and its role in Modern Society," organised by the Aal al-Bayt Institute for Islamic Thought, 4-6 July 2005, 2.

25. Nikkie R. Kiddie, “The Revolt of Islam from 1700 to 1993," in Islam: Critical Concepts in Sociology, ed. Bryan S. Turner (Oxford: Routledge, 2003), vol. 2, 89.

26. Cf., Ahmad Zahid Hamidi, 'De-rooting radicalism and extremism,' New Straits Times, 14 November 2016.

27. http://www.nieuwwij.nl/english/karen-armstrong-islam-violent-christianity/ (accessed 18 March 2015)

28. Saleena Saleem, 'It's More Politics than Religion,' New Straits Times, 24 March 2016. 
29. Fareed Zakaria, 'Radicals before they were religious,' New Straits Times, 2 April 2016.

30. Ibid.

31. Azhari Karim, 'Dealing with different types of terrorists,' New Straits Times, 19 July 2016.

32. Ibid.

33. Peter Apps, 'Is Europe overreacting to terror?' New Straits Times, 3 September 2016.

34. Mahmud Shaltut, al-Islam 'Aqida wa Shariah, 328; 'Awdah, al-Tashri', 446; Zuhayli, Huquq al-Insan, 144.

35. 'Awdah, 447

36. Cf., Al-'Ibadi, Min al-Adab Wa'l-Akhlaq, 164-5.

37. Abd-Allah al-Khatib al-Tabrizi, Mishkat al-Masabih, $2^{\text {nd }}$ ed., Muhammad Nasir al-din al-Albani (Beirut: Al-Maktab al-Islami, 1979/1399) Vol II, hadith no: 3453.

38. Bukhari, Sahih al-Bukhari, Kitab al-adab b ma yunha 'anhu min al-sibab.

39. Bukhari, Sahih al-Bukhari (Muhsin Khan's trans.), VIII, 330, hadith 500.

40. See for details, Ghazi bin Muhammad, Ibrahim Kalin and Mohammad Hashim Kamali, War and Peace in Islam: The Uses and Abuses of Jihad, (Cambridge: The Islamic Texts Society, 2013), Introduction by Kamali at xv.

41. www.utusan.com.my/utusan/content.asp? $y=2003 \& d t=1111 \& p u b=u t u s a n$ Express.

42. Shaykh Mahmud Shaltut, 'Warfare in the Qur'an', trans. Joel Howard, in War and Peace in Islam, ed. Ghazi et al (Cambridge: The Islamic Texts Society, 2013), (note 18 above), 43.

43. Shaykh Muhammad Sayyid Tantawi as quoted by Anicee Van Engeland Nourai: 'The Challenge of Fragmentation of International Humanitarian Law,' in Jihad and Its Challenges, ed. M. Cheriff Bassiouni (The Hague: Hague Academic Press, 2010), 147.

44. As quoted in Seyyed Hossein Nasr, The Heart of Islam: Enduring Values for Humanity (New York: Harper Collins Publishers, 2004), 263.

45. Quoted in Anicee Nourai, 'The Challenge of Fragmentation,' 148.

46. Caryle Murphy, 'US Muslim Scholars to Forbid Terrorism,' Washington Post. Available at http://www.washingtonpost.com/wp-dyn/content/ article/2005/07/27/AR2005072702082.html

47. Cf., Farish Noor, 'Radicalism's pool of support,' New Straits Times, 25 August 2014.

48. Amnesty International, Escape from Hell: Torture and Sexual Slavery in Islamic State Captivity in Iraq (London: Amnesty International Ltd., 2014).

49. Mark L. Winer, 'Fundamentalists vs. Moderates: the War within Judaism,' Arches Quarterly 5, no. 9, (2012): 3-10.

50. Scott Thompson, 'Liberty’s 9/11,' New Straits Times, 14 January, 2015.

51. All of these maxims appear in the Majallah ekl-Ahkam el-Adliye, as also in Mohammad Hashim Kamali, Shariah Law: An Introduction, Oxford: Oneworld Publications, 2008, 146ff where the reader can also find discussions on and illustrations of these various maxims on darar. 